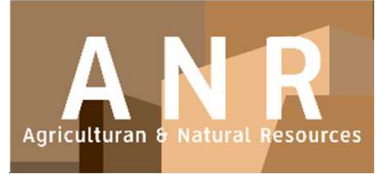

PAPER - OPEN ACCESS

\title{
Pertumbuhan Shorea selanica Dan Melinjo (Gnetum gnemon Linn.) Pada Media Tanam Dengan Konsentrasi Cocopeat Yang Berbeda
}

\author{
Author $\quad:$ Arum Sekar Wulandari dan Teguh Artha \\ DOI $\quad: 10.32734 /$ anr.v3i1.830 \\ Electronic ISSN : :2654-7023 \\ Print ISSN : $2654-7015$
}

Volume 3 Issue 1 - 2020 TALENTA Conference Series: Agriculturan \& Natural Resource (ANR)

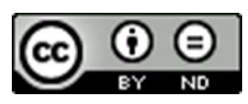

This work is licensed under a Creative Commons Attribution-NoDerivatives 4.0 International License.

Published under licence by TALENTA Publisher, Universitas Sumatera Utara

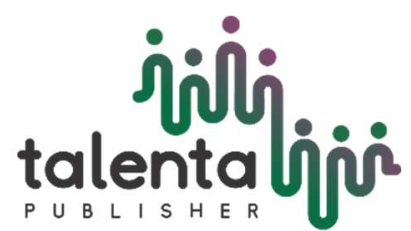




\title{
jibiti

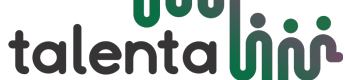 TALENTA Conference Series
}

Available online at https://talentaconfseries.usu.ac.id/anr

\section{Pertumbuhan Shorea selanica Dan Melinjo (Gnetum gnemon Linn.) Pada Media Tanam Dengan Konsentrasi Cocopeat Yang Berbeda}

\author{
Arum Sekar Wulandari ${ }^{\mathrm{a}}$ dan Teguh Artha $^{\mathrm{a}}$ \\ ${ }^{a}$ Departemen Silvikultur, Fakultas Kehutanan, IPB University, Kampus IPB Darmaga Bogor 16168, Indonesia. \\ rr_arum@yahoo.com
}

\begin{abstract}
Abstrak
Cocopeat adalah serbuk halus sabut kelapa yang dihasilkan dari proses penghancuran sabut kelapa. Cocopeat dapat dijadikan sebagai media tanam atau campuran media tanam. Penelitian ini bertujuan mendapatkan konsentrasi cocopeat yang tepat dalam media tanam yang dapat mendukung pertumbuhan bibit Shorea selanica dan melinjo (Gnetum gnemon). Penelitian dilakukan di rumah kaca dengan menggunakan rancangan acak lengkap 2 faktor. Faktor pertama ialah jenis tanaman ( S. selanica dan melinjo). Faktor kedua ialah konsentrasi cocopeat dalam media tanam $(0 \%, 10 \%, 20 \%, 30 \%)$. Hasil penelitian menunjukkan bahwa penambahan cocopeat dalam media tanam dapat meningkatkan pertumbuhan bibit $S$. selanica dan melinjo. Bibit $S$. selanica yang ditanam pada media tanam dengan konsentrasi cocopeat $10 \%$ mempunyai tinggi, diameter, biomassa, dan panjang akar primer yang lebih tinggi dibandingkan dengan kontrol. Bibit melinjo yang ditanam pada media tanam dengan konsentrasi cocopeat $20 \%$ mempunyai tinggi, diameter, dan berat kering pucuk yang lebih tinggi dibandingkan dengan kontrol. Secara umum, penambahan cocopeat sebanyak 10-20\% dapat meningkatkan pertumbuhan bibit S. selanica dan melinjo.
\end{abstract}

Kata Kunci: Cocopeat; Gnetum gnemon; media tanam; pertumbuhan bibit; Shorea selanica

\section{Pendahuluan}

Media tanam berfungsi sebagai tempat melekatnya akar dan sebagai penyedia hara bagi tanaman. Komponen media tanam umumnya terdiri atas tanah, bahan organik, air, dan udara. Media tanam sebaiknya tidak hanya terdiri atas tanah [1], namun juga memungkinkan untuk mencampurkan berbagai jenis media tanam lain seperti pasir, cocopeat, arang sekam, kompos, dan sebagainya. Pencampuran beberapa bahan untuk media tanam dapat membuat struktur tanah menjadi lebih baik, sehingga mendukung untuk pertumbuhan tanaman. Penambahan kompos dengan konsentrasi $25 \%$ dalam media tanam dapat meningkatkan biomassa dan jumlah bunga tanaman hias Begonia semperflorens "Bellavista F1", Mimulus "Magic $£$ hybridus", Salvia splendens "maestro", and Tagete patula $\mathrm{x}$ erecta "Zenith Lemon Yellow" [2]. Hal yang sama ditemukan dalam penelitian [3], pemberian kompos dengan konsentrasi $25-75 \%$ dapat meningkatkan tinggi dan diameter bibit cemara.

Media tanam pasir mempunyai kemampuan menyimpan air sangat rendah sehingga lebih cepat kering, berat dan harganya mahal. Oleh karena itu, perlu adanya campuran media tanam alternatif sebagai pengganti pasir, salah satunya ialah cocopeat. Cocopeat adalah serbuk halus sabut kelapa yang dihasilkan dari proses penghancuran sabut kelapa. Keunggulan cocopeat sebagai media tanam antara lain: mempunyai kapasitas menahan air yang tinggi; drainase yang sangat baik; tidak adanya gulma dan pathogen; mempunyai ketahanan fisik yang baik; dekomposisi lambat; mudah menyerap air; mengandung karbon yang sangat tinggi; dan banyak tersedia [4]; $\mathrm{pH}$ netral; kapasitas pertukaran kation baik; dan konduktivitas listrik baik; jumlah ion kalium, natrium dan klorida lebih tinggi daripada fosfor, zat besi dan kalsium [5]. Dengan sifatnya yang demikian, cocopeat dapat digunakan sebagai campuran dalam media tanam, dan dapat meningkatkan pertumbuhan bibit Gmelina arborea dan Acacia mangium [6]. Kelemahan cocopeat sebagai 
campuran dalam media tanam ialah adanya senyawa fenolik dalam substrat dan yang larut dalam air. Senyawa fenolik ini bersifat fitotoksik sehingga dapat mempengaruhi pertumbuhan tanaman. Penambahan cocopeat dalam media tanam dapat menghambat pertumbuhan akar selada [7], menghambat petumbuhan Eucalyptus urophylla dan E. deglupta [8]. Berdasarkan fakta-fakta di atas, pencampuran media tanam dapat memberikan efek positif maupun negatif terhadap pertumbuhan tanaman. Oleh karena itu perlu dicari komposisi yang tepat dari pencampuran bahan dalam media tanam. Penelitian ini bertujuan mendapatkan konsentrasi cocopeat yang tepat dalam media tanam yang dapat mendukung pertumbuhan bibit Shorea selanica dan melinjo (Gnetum gnemon).

\section{Metode Penelitian}

\subsection{Persiapan Bahan}

Persiapan Media Tanam. Media tanam yang digunakan merupakan campuran dari tanah, dan kompos dengan perbandingan 1:1 (v/v). Campuran media tersebut kemudian ditambahkan arang sekam dengan konsentrasi 10\% [9] dan diaduk secara merata. Sebagai perlakuan ke dalam campuran tanah, kompos, dan arang sekam; ditambahkan cocopeat dengan konsentrasi $0 \%, 10 \%, 20 \%$, dan 30\%. Konsentrasi cocopeat $0 \%$ berarti dalam media tanam tidak ditambahkan cocopeat (sebagai kontrol). Media yang sudah tercampur secara merata, kemudian dimasukkan ke dalam polibag.

Persiapan Bahan Tanaman. Benih S. selanica yang digunakan berasal dari Hutan Penelitian Haurbentes, Jasinga, Bogor. Benih kemudian dikecambahkan di rumah kaca. Kecambah S. selanica yang telah mempunyai sepasang daun siap digunakan untuk penelitian. Bibit melinjo yang digunakan dalam penelitian ini diperoleh dari penjual bibit di Ciapus, Bogor. Bibit melinjo yang digunakan adalah bibit yang mempunyai sepasang daun.

Penanaman Bibit. Media tanam yang telah disiapkan disiram dengan air sampai jenuh. Bibit S.selanica dan melinjo yang sudah disiapkan dipindahkan ke dalam polibag yang telah berisi media tanam dengan konsentrasi cocopeat sesuai perlakuan. Bibit ditempatkan di tempat yang teduh selama 1 minggu untuk adaptasi terhadap lingkungan media yang baru, setelah itu dipindahkan ke dalam rumah kaca. Peletakan bibit di rumah kaca sesuai dengan layout rancangan acak lengkap.

Pemeliharaan bibit S. selanica dan melinjo yang dilakukan di rumah kaca meliputi penyiraman, penyiangan gulma, dan pengendalian hama. Penyiraman bibit dilakukan 1 hari sekali. Penyiangan gulma dan pengendalian hama dilakukan secara manual.

Bibit $S$. selanica dan melinjo ditumbuhkan .dan diamati di dalam rumah kaca selama 20 minggu. Tinggi bibit $S$. selanica dan melinjo diukur setiap 2 minggu, mulai minggu pertama sampai minggu ke-20 setelah bibit disapih. Pengukuran diameter batang dilakukan 6 minggu sekali, mulai minggu pertama sampai minggu ke-20 setelah bibit disapih. Pada akhir pengamatan (minggu ke-20) ditetapkan biomassa pucuk dan akar, dan dilakukan pengukuran akar. Pengukuran berat basah dan kering pucuk dan akar dilakukan dengan cara memisahkan bibit dari media tanam, kemudian akar dicuci dari kotoran yang menempel. Setelah bersih, bagian pucuk dan akar dipisahkan. Pucuk dan akar ditimbang berat basahnya. Berat basah total diperoleh dengan cara menjumlahkan berat basah pucuk dan akar. Untuk mendapatkan data berat kering, bagian pucuk dan akar dikeringkan dalam oven pada suhu $70{ }^{\circ} \mathrm{C}$ selama 120 jam, kemudian ditimbang beratnya. Pemeriksaan akar dilakukan dengan mengukur panjang akar primer dan akar sekunder terpanjang.

\subsection{Rancangan Percobaan dan Analisis Data}

Rancangan percobaan yang digunakan adalah rancangan acak lengkap (RAL) dengan dua faktor. Faktor pertama adalah jenis tanaman yang terdiri dari 2 taraf, yaitu $S$. selanica dan melinjo. Faktor kedua adalah konsentrasi cocopeat yang terdiri atas 4 taraf, yaitu $0 \%, 10 \%, 20 \%$, dan 30\%). Masing-masing perlakuan diulang sebanyak 5 kali, dan satu ulangan terdiri atas 4 bibit $S$. selanica atau melinjo.

Data yang diperoleh dari hasil pengamatan diuji dengan sidik ragam (anova) pada taraf kesalahan 5\%. Apabila ada perbedaan nyata, maka akan diuji dengan menggunakan Duncan Multiple Range Test (DMRT). Pengolahan data dilakukan dengan menggunakan software SAS 9 1.3 portable. 


\section{Hasil dan Pembahasan}

Salah satu faktor yang mempengaruhi pertumbuhan tanaman adalah media tanam yang digunakan. Media tanam yang baik adalah media yang mampu menyediakan air dan unsur hara dalam jumlah cukup bagi pertumbuhan tanaman. Hal ini dapat ditemukan pada tanah dengan tata udara yang baik, mempunyai agregat mantap, kemampuan menahan air yang baik dan ruang untuk perakaran yang cukup. Penanaman bibit dalam pot dapat dilakukan dengan menggunakan campuran berbagai jenis media tanam seperti: pasir, serbuk gergaji, arang sekam, cocopeat, zeolit, vermikulit dan perlit [10].

Tabel 1. Pengaruh konsentrasi cocopeat terhadap pertumbuhan bibit Shorea selanica dan melinjo selama 20 minggu pengamatan

\begin{tabular}{lllll}
\hline \multirow{2}{*}{ Cocopeat $(\%)$} & \multicolumn{2}{l}{ Pertambahan tinggi $(\mathrm{cm})^{*}$} & \multicolumn{2}{l}{ Pertambahan diameter $(\mathrm{mm})^{*}$} \\
\cline { 2 - 5 } & Shorea selanica & melinjo & Shorea selanica & Melinjo \\
\hline 0 & $2.40^{\mathrm{a}}$ & $6.00^{\mathrm{a}}$ & $0.84^{\mathrm{a}}$ & $0.79^{\mathrm{a}}$ \\
10 & $3.20^{\mathrm{b}}$ & $6.96^{\mathrm{a}}$ & $1.00^{\mathrm{b}}$ & $0.41^{\mathrm{a}}$ \\
20 & $1.50^{\mathrm{a}}$ & $11.67^{\mathrm{b}}$ & $0.59^{\mathrm{a}}$ & $0.95^{\mathrm{b}}$ \\
30 & $2.36^{\mathrm{a}}$ & $11.35^{\mathrm{b}}$ & $0.71^{\mathrm{a}}$ & $0.44^{\mathrm{a}}$ \\
\hline
\end{tabular}

*: angka-angka pada kolom yang sama yang diikuti oleh huruf yang sama tidak berbeda nyata pada taraf uji 5\% (Uji Jarak Berganda Duncan).

Penambahan cocopeat pada media tanan berpengaruh terhadap pertumbuhan tinggi dan diameter bibit $S$. selanica dan melinjo. Pada bibit S. selanica, penambahan cocopeat dengan konsentrasi $10 \%$ dalam media tanam dapat meningkatkan pertumbuhan tinggi bibit sebesar 33\% dibandingkan dengan kontrol; dan meningkatkan diameter bibit sebesar 19\%. Pada bibit melinjo, penambahan cocopeat dengan konsentrasi $20 \%$ dan $30 \%$ pada media tanam memberikan hasil yang sama terhadap peningkatan tinggi bibit melinjo. Tinggi bibit melinjo meningkat sebesar 8995\% dibandingkan dengan kontrol. Sedangkan pada peubah diameter, penambahan cocopeat dengan konsentrasi $20 \%$ pada media tanam dapat meningkatkan tinggi bibit melinjo sebesar 20\% dibandingkan dengan kontrol (Tabel 1).

Sifat kimia substrat yang digunakan sebagai media tanam berkorelasi sangat kuat dengan pertumbuhan tanaman, sehingga pemilihan substrat yang sesuai untuk pertumbuhan bibit yang berkualitas baik sangat diperlukan [5]. Sifatsifat kimia dari masing-masing campuran bahan dan interaksi antar bahan yang menyusun media tanam mempengaruhi pertumbuhan tanaman dan kecukupan nutrisi tanaman pada tingkat dan efek yang bervariasi, bergantung pada jenis dan umur dari bibit [11]. Campuran berbagai media tanam yang sesuai dapat meningkatkan biomassa dan jumlah bunga pada tanaman hias Zinnia elegans cv. Blue Point [12]. Pada Pinus halepensis M. campuran media tanam yang terdiri atas kompos kenaf (Hibiscus cannabinus L.) dan sekam padi dapat meningkatkan pertumbuhan tinggi dan diameter Pinus halepensis M.[13]. Campuran media tanam organik berupa arang sekam, cocopeat, pelepah/batang pisang, dan tanah memberikan pengaruh yang sangat nyata terhadap jumlah daun per tanaman, jumlah anakan per tanaman, berat brangkasan basah akar, berat brangkasan basah bagian atas tanaman, berat brangkasan kering akar dan berat brangkasan kering bagian atas tanaman stroberi [14].

Tabel 2. Pengaruh konsentrasi cocopeat terhadap pertumbuhan bibit Shorea selanica dan melinjo selama 20 minggu pengamatan

\begin{tabular}{|c|c|c|c|c|}
\hline \multirow{2}{*}{ Cocopeat $(\%)$} & \multicolumn{2}{|c|}{ Berat kering pucuk $(\mathrm{cm})^{*}$} & \multicolumn{2}{|c|}{ Berat kering akar $(\mathrm{mm})^{*}$} \\
\hline & Shorea selanica & melinjo & Shorea selanica & Melinjo \\
\hline 0 & $0.44^{\mathrm{a}}$ & $0.59^{\mathrm{a}}$ & $0.15^{\mathrm{ab}}$ & $0.26^{\mathrm{a}}$ \\
\hline 10 & $0.33^{\mathrm{a}}$ & $0.69^{\mathrm{a}}$ & $0.17^{\mathrm{b}}$ & $0.28^{\mathrm{a}}$ \\
\hline 20 & $0.32^{\mathrm{a}}$ & $0.84^{\mathrm{b}}$ & $0.08^{\mathrm{a}}$ & $0.26^{\mathrm{a}}$ \\
\hline 30 & $0.31^{\mathrm{a}}$ & $0.54^{\mathrm{a}}$ & $0.12^{\mathrm{a}}$ & $0.40^{\mathrm{b}}$ \\
\hline
\end{tabular}

*: angka-angka pada kolom yang sama yang diikuti oleh huruf yang sama tidak berbeda nyata pada taraf uji 5\% (Uji Jar Berganda Duncan).

Penambahan cocopeat dalam media tanam belum dapat meningkatkan berat kering pucuk bibit S. selanica, tetapi sudah dapat meningkatkan berat kering pucuk bibit melinjo. Berat kering pucuk melinjo yang ditanam pada media 
dengan penambahan cocopeat $20 \%$ meningkat sebesar $42 \%$ dibandingkan dengan kontrol. Penambahan cocopeat dalam media tanam dapat meningkatkan berat kering akar bibit $S$. selanica dan melinjo. Penambahan cocopeat dengan konsentrasi $10 \%$ dapat meningkatkan berat kering akar S. selanica sebesar $13 \%$ dibandingkan dengan kontrol, sedangkan pada bibit melinjo, penambahan cocopeat dengan konsentrasi 30\% dapat meningkatkan berat kering akar melinjo sebesar 54\% dibandingkan dengan kontrol (Tabel 2).

Kelebihan cocopeat sebagai campuran atau pengganti media tanam bibit telah dikemukakan oleh [4] serta [5]. Aplikasi cocopeat juga tidak mempengaruhi hasil dari perlakuan pemupukan pada tanaman target [10]-[11]. Bibit red oak yang ditanam pada media cocopeat pertumbuhannya lebih baik dibandingkan dengan yang ditanam pada media peat moss (gambut), sehingga fungsi peat moss dapat digantikan oleh cocopeat. Beberapa hal yang menjadikan cocopeat dapat digunakan sebagai alternatif pengganti peat moss ialah: (1) membantu pelestarian ekosistem gambut, (2) mempunyai stabilitas fisik, kemudahan untuk menyerap air/larutan hara, kemampuan menahan kompresi, dan (3) laju penyusutan yang rendah dari waktu ke waktu [11].

Tabel 3. Pengaruh konsentrasi cocopeat terhadap perkembangan akar primer dan sekunder bibit Shorea selanica dan melinjo selama 20 minggu pengamatan

\begin{tabular}{|c|c|c|c|c|}
\hline \multirow{2}{*}{ Cocopeat $(\%)$} & \multicolumn{2}{|c|}{ Panjang akar primer $(\mathrm{cm})^{*}$} & \multicolumn{2}{|c|}{ Panjang akar sekunder $(\mathrm{mm})^{*}$} \\
\hline & Shorea selanica & melinjo & Shorea selanica & melinjo \\
\hline 0 & $14.08^{\mathrm{a}}$ & $7.87^{\mathrm{a}}$ & $5.47^{\mathrm{a}}$ & $3.82^{\mathrm{a}}$ \\
\hline 10 & $14.44^{\mathrm{a}}$ & $13.88^{\mathrm{b}}$ & $5.50^{\mathrm{a}}$ & $9.09^{\mathrm{b}}$ \\
\hline 20 & $10.73^{\mathrm{a}}$ & $12.43^{\mathrm{b}}$ & $9.18^{\mathrm{b}}$ & $7.36^{\mathrm{b}}$ \\
\hline 30 & $14.97^{\mathrm{a}}$ & $14.16^{\mathrm{b}}$ & $7.53^{\mathrm{ab}}$ & $10.83^{\mathrm{b}}$ \\
\hline
\end{tabular}

*: angka-angka pada kolom yang sama yang diikuti oleh huruf yang sama tidak berbeda nyata pada taraf uji 5\% (Uji Jar Berganda Duncan).

Penambahan cocopeat dalam media tanam belum dapat meningkatkan panjang akar primer bibit $S$. selanica, tetapi sudah dapat meningkatkan panjang akar primer bibit melinjo. Peningkatan panjang akar primer melinjo yang ditanam pada media dengan konsentrasi cocopeat $10 \%$ sama hasilnya dengan yang ditanam pada media dengan konsentrasi cocopeat $20 \%$ dan 30\%. Sebagai rekomendasi untuk aplikasi ialah penambahan cocopeat dengan konsentrasi $10 \%$ karena dengan konsentrasi yang lebih rendah (biaya lebih sedikit) memberikan hasil yang sama. Panjang akar primer melinjo yang ditanam pada media dengan penambahan cocopeat $10 \%$ meningkat sebesar $76 \%$ dibandingkan dengan kontrol. Penambahan cocopeat dalam media tanam dapat meningkatkan panjang akar sekunder bibit $S$. selanica dan melinjo. Penambahan cocopeat dengan konsentrasi 20\% dapat meningkatkan panjang akar sekunder S. selanica sebesar $67.8 \%$ dibandingkan dengan kontrol. Peningkatan panjang akar sekunder melinjo yang ditanam pada media dengan konsentrasi cocopeat $10 \%$ sama hasilnya dengan yang ditanam pada media dengan konsentrasi cocopeat $20 \%$ dan 30\%. Sebagai rekomendasi untuk aplikasi ialah penambahan cocopeat dengan konsentrasi $10 \%$ karena dengan konsentrasi yang lebih rendah (biaya lebih sedikit) memberikan hasil yang sama. Penambahan cocopeat dengan konsentrasi 10\% dapat meningkatkan panjang akar sekunder melinjo sebesar 137.96\% dibandingkan dengan kontrol (Tabel 3).

Fungsi akar bagi tanaman yaitu membantu tumbuhan agar dapat berdiri kokoh di dalam tanah, menyerap air dari tanah serta menyerap unsur hara dari tanah. Akar primer berguna untuk perluasan jangkauan dalam penyerapan unsur hara. Semakin panjang akar primer maka akan berpengaruh pada kedalaman akar menembus solum tanah. Kedalaman perakaran sangat berpengaruh pada banyaknya air yang dapat diserap tanaman. Makin panjang dan dalam akar menembus tanah, maka makin banyak air yang dapat diserap [15].

Secara umum, penambahan cocopeat 10-20\% dalam media tanam dapat meningkatkan pertumbuhan bibit $S$. selanica dan melinjo. Bibit $S$. selanica yang ditanam pada media tanam dengan konsentrasi cocopeat $10 \%$ mempunyai tinggi, diameter, biomassa, dan panjang akar primer yang lebih tinggi dibandingkan dengan kontrol. Bibit melinjo yang ditanam pada media tanam dengan konsentrasi cocopeat $20 \%$ mempunyai tinggi, diameter, dan berat kering pucuk yang lebih tinggi dibandingkan dengan kontrol. 


\section{Kesimpulan}

Pada bibit $S$. selanica, penambahan cocopeat dalam media tanam dapat meningkatkan pertumbuhan tinggi, diameter, berat kering akar, panjang akar primer, dan panjang akar sekunder; tetapi belum dapat meningkatkan berat kering pucuk. Konsentrasi cocopeat dalam media tanam yang direkomendasikan untuk bibit S. selanica ialah $10 \%$. Pada bibit melinjo, penambahan cocopeat dalam media tanam dapat meningkatkan pertumbuhan tinggi, diameter, berat kering pucuk dan akar, panjang akar primer, dan panjang akar sekunder. Konsentrasi cocopeat dalam media tanam yang direkomendasikan untuk bibit melinjo ialah $20 \%$.

\section{Referensi}

[1] Landis T.D. and Morgan N. (2009) "Growing media alternatives for forest and native plant nurseries." USDA Forest Service Proceedings RMRS-P-58:26-31.

[2] Grigatti M., Giorgioni M.E., and Ciavatta C. (2007) "Compost-based growing media: Influence on growth and nutrient use of bedding plants." Bioresource Technology 98: 3526-3534.

[3] Lopez R, Cabrera F, Madejon E, Sancho F, Alvarez J.M. (2008) "Urban composts as an alternative for peat in forestry nursery growing media." Dynamic Soil, Dynamic Plant 2 (1): 60-66.

[4] Rose R, and Haase D. (2000) “The use of coir as a containerized growing medium for douglas-fir seedlings." Refereed Research Article $\mathbf{1}$ (2): 107-111.

[5] Jeyaseeli D,M. and Raj S.P. (2010) "Chemical characteristics of coir pith as a function of its particle size to be used as soilless medium." An International Quarterly Journal of Environmental Sciences 4 (2 \& 3): 163-169.

[6] Reddell P, Webb M.J., Poa D, Aihuna D. (1999) “Incorporation of slow-release fertilisers into nursery media.” New Forests 18: $277-287$.

[7] Ma Y.B. and Nichols D.G. (2004) "Phytotoxicity a.nd detoxification of fresh coir dust and coconut shell." Commun Sol Sci Plant Annal 35: 205-218.

[8] Radjagukguk B. dan Soeseno O. (1983) "A comparative study of peat and other media for containerized forest tree seedlings." Acta Horticultura 1: 449-458.

[9] Supriyanto dan Fiona F. (2010) "Pemanfaatan arang sekam untuk memperbaiki pertumbuhan semai jabon (Anthocephalus cadamba (Roxb.) Miq) pada media subsoil." Jurnal Silvikultur Tropika 1 (1): 24 - 28.

[10] Landis T.D., Jacobs D.F., Wilkinson K.M., Luna T. (2014) “Growing media”, in Wilkinson KM, Landis TD, Haase DL, Daley BF, Dumroese RK. (eds) Tropical Nursery Manual: A Guide to Starting and Operating a Nursery for Native and Traditional Plants, USA, United States Department of Agriculture, pp. 101-121.

[11] Salifu K.F., Nicodemus M.A., Jacobs D.F., Davis As. (2006) "Evaluating chemical indices of growing media for nursery production of Querqus rubra seedlings." Hort Science 41 (5): 1342-1346.

[12] Riaz A, Arshad M, Younis A, Raza A, Hameed M. (2008) "Effects of different growing media on growth and flowering of Zinnia elegans cv." Blue Point. Pak. J. Bot. 40 (4): 1579-1585.

[13] Marianthi T. (2005) "Kenaf (Hibiscus cannabinus L.) core and rice hulls as components of container media for growing Pinus halepensis M. seedlings." Bioresource Technology 97: 1631-1639.

[14] Pratiwi N.E., Simanjuntak B.H., Banjarnahor D. (2007) "Pengaruh campuran media tanam terhadap pertumbuhan tanaman stoberi (Fragaria vesca L.) sebagai tanaman hias tanam vertikal." Agric. 29 (1): 11-20.

[15] Kumar V. (2015) “Growing media for healthy seedling production.” Van Sangyan 2 (9): 19-28. 